\title{
SENYAWA FENOL PADA TOLERANSI Falcataria moluccana (Miq.) TERHADAP PENYAKIT KARAT TUMOR
}

Phenolic compounds in Falcataria moluccana (Miq.) gall rust disease tolerance

\author{
Asri Insiana Putri ${ }^{1}$, Mohammad Na'iem², Sapto Indrioko ${ }^{2}$, dan Sri Rahayu ${ }^{2}$ \\ ${ }^{1}$ Balai Besar Penelitian Bioteknologi dan Pemuliaan Tanaman Hutan \\ Jl. Palagan Tentara Pelajar Km. 15, Purwobinangun, Pakem, Sleman, Yogyakarta, Indonesia \\ e-mail: asriip@yahoo.co.id \\ ${ }^{2}$ Fakultas Kehutanan, Universitas Gadjah Mada \\ J1. Agro No. 1, Bulaksumur, Sleman, Yogyakarta, Indonesia
}

Tanggal diterima : 31 Juni 2015, Tanggal direvisi : 18 Agustus 2015, Disetujui terbit : 10 November 2015

\begin{abstract}
Falcataria moluccana (Miq.) is severely attacked by Uromycladium tepperianum (Sacc.) McAlpine, which is a gall-forming (neoplasmic) and parasitic obligate pathogen. Phenolic compounds have the ability to function as co-factors of pathogenicity determinant of pathogens development and chemical defenses of plants. The purpose of this study was to determine the content of phenolic compounds on gall rust tolerance sengon by observation of tolerant sengon height, quantitative analysis of total phenolic compounds, wood anatomy analysis and tolerance test of sengon callus from tissue culture with filtrate gall rust as chemical agent. The results of the research were (1) inoculated sengon have lower total phenolic compounds than the control (no inoculation), (2) tolerant sengon have lower content of phenolic compounds than sensitive one, (3) microscopic wood anatomy observation shows that tolerant sengon have darker substrat, and (4) in the same concentration of gall rust filtrate incubation media, the tolerant sengon have higher survival cell calli. The highest concentration that callus cells can survive was $25 \%(\mathrm{v} / \mathrm{v})$.
\end{abstract}

Keywords: $\quad$ phenolic compounds, Falcataria moluccana, tolerant, Uromycladium tepperianum, anatomy, live callus cells

\begin{abstract}
ABSTRAK
Penyakit karat tumor menyerang secara luas pada sengon ( $F$. moluccana Miq.), membentuk tumor (neoplasmik) yang disebabkan oleh patogen obligat parasit Uromycladium tepperianum (Sacc.) McAlpine. Senyawa fenol mempunyai kemampuan berfungsi sebagai co-factor penentu patogenisitas dari hasil perkembangan patogen dan pertahanan kimia tanaman. Tujuan penelitian ini adalah untuk mengetahui kandungan senyawa fenol pada toleransi sengon terhadap karat tumor dengan melakukan pengamatan tinggi tanaman, analisis kuantitatif senyawa fenol total, analisis anatomi kayu sengon toleran dan uji toleransi kalus sengon hasil budidaya jaringan dengan filtrat karat tumor sebagai agen kimia. Hasil penelitian ini adalah (1) sengon yang diinokulasi spora karat tumor mempunyai senyawa fenol total yang lebih rendah dibandingkan kontrol (tanpa inokulasi), (2) sengon toleran karat tumor mempunyai kandungan senyawa fenol lebih rendah dibandingkan sengon yang sensitif, (3) hasil mikroskopis anatomi kayu menunjukkan adanya kandungan substrat yang lebih gelap pada sengon tidak toleran dan (4) pada media filtrat karat tumor dengan konsentrasiyang sama, sengon toleran menunjukkan sel-sel kalus hidup yang lebih tinggi. Konsentrasi tertinggi sel kalus dapat hidup adalah $25 \%(\mathrm{v} / \mathrm{v})$.
\end{abstract}

Kata kunci: senyawa fenol, Falcataria moluccana, Uromycladium tepperianum, toleran, anatomi, sel hidup kalus 


\section{PENDAHULUAN}

Sengon di Indonesia mengalami serangan penyakit karat tumor (gall rust) yang disebabkan oleh Uromycladium tepperianum secara cepat dan luas di berbagai wilayah. Semakin meluasnya budidaya sengon berpotensi meningkatkan intensitas serangan penyakit karat tumor di berbagai wilayah. Kematian $100 \%$ pada bibit akibat karat tumor, serangan $21,47 \%$ pada tegakan umur 3 tahun dan serangan $100 \%$ untuk tegakan 5 tahun telah terjadi di pulau Seram, Maluku (Anggraeni, 2008).

Walaupun jamur karat telah dikenal sebagai patogen penting dalam kurun waktu yang lama, penelitian mengenai hal ini mengalami banyak kesulitan karena jamur karat (rust fungi) bersifat obligat biotrop tidak dapat dibudidayakan in vitro (paling tidak pada saat tahap parasitik), membentuk banyak perbedaan struktur infeksi dari bentuk sel tubuler normal yang biasa terjadi pada patogen, mempunyai aktivitas sekresi terbatas, mempunyai zona kontak yang sempit antara jamur dan membran plasma inang, dapat menekan tanggapan ketahanan inang pada jangka waktu yang panjang dan dapat membentuk haustoria (hifa khusus yang menetrasi sel inang) (Voegele and Mendgen, 2010). Sampai saat ini penelitian untuk mengatasi hambatan karakter spesifik karat tumor pada sengon dengan pendekatan biokimia dan in vitro belum dilaporkan.

Pendekatan dasar dari strategi pemuliaan adalah seleksi buatan terhadap individu-individu untuk mendapatkan tanaman toleran penyakit (Scheffer, 2007; Maloy, 2005; Finkeldey, 2005). Toleransi melibatkan beberapa tingkat kompensasi dari kerusakan akibat serangan penyakit dan dapat mengurangi atau mengimbangi infeksi diantaranya secara morfologi dan biokimia (Paige \& Whitham, 1987; Marquis, 1992; Rosenthal \& Welter, 1995; Strauss \& Agrawal, 1999).

Penurunan tingkat kompensasi kerusakan akibat serangan penyakit dapat dilakukan tanaman dengan menghasilkan metabolik sekunder fenol, senyawa penting dari sistem pertahanan terhadap serangan patogen yang dihasilkan sebagai bagian dari pertumbuhan tanaman secara normal atau adanya tekanan lingkungan biotik maupun abiotik. Fenol adalah kelompok fungsional hidroksil pada cincin aromatik. Fenol total terdiri dari senyawa koumarin, furano-koumarin, ligin, flavonoid, isoflavonoid dan tannin (Lattanzio et al., 2006).

Sistem pertahanan memerlukan realokasi energi dan perubahan aktivitas fisiologis tanaman inang (Simms \& Rausher 1987; Herms \& Mattson 1992; Simms \& Triplett 1994; Bergelson \& 
Purrington 1996; Mauricio et al., 1993), serta peningkatan reaksi aktivasi seperangkat gen pengkode protein penginduksi biokimia penting yaitu protein terkait patogenesis (Pathogenesis Related Protein) (Ebrahim et al., 2011). Sistem pertahanan sengon terhadap serangan patogen $U$. tepperianum yang bersifat obligat biotrop parasit memerlukan penelitian perubahan aktivitas fisiologis yaitu senyawa biokimia terinduksi diantaranya fenol total dalam upaya menekan realokasi energi yang seharusnya dipergunakan untuk pertumbuhan dan perkembangan melalui sengon toleran karat tumor.

\section{BAHAN DAN METODE}

\section{A. Lokasi penelitian}

Lokasi penelitian untuk kegiatan in vitro dan pengamatan mikroskopis fluorescen dilakukan di Laboratorium Budidaya Jaringan Balai Besar Penelitian Bioteknologi dan Pemuliaan Tanaman Hutan, Yogyakarta. Analisis senyawa metabolik sekunder dilakukan di Lembaga Penelitian dan Pengujian terpadu UGM. Pengamatan mikroskopis anatomi dilakukan di Laboratorium Anatomi Kayu, Fakultas Kehutanan, UGM.

\section{B. Bahan penelitian}

Bahan yang digunakan pada penelitian ini adalah cabang tanaman $F$. moluccana hasil seleksi inokulasi buatan spora karat tumor di persemaian umur 1,5 tahun hasil penelitian terdahulu. Gal (gall) segar sengon yang sudah menghasilkan spora diperoleh dari alam umur 2 tahun dipergunakan untuk ekstraksi filtrat sebagai agen seleksi kalus dan untuk analisis senyawa fenol total. Kalus diperoleh dari plantlet hasil budidaya jaringan tunas aksiler sengon hasil seleksi. Bahan kimia utama adalah pereaksi FolinCiocalteu, asam galat, larutan glutaral dehid (larutan fiksasi), etanol 30\%, safranin 1\%, xylol, dan canada balsam, fluorescence diacetic acid, aquadest steril dan media Murashige Skoog.

\section{Alat penelitian}

Alat-alat utama untuk penelitian ini adalah spektrofotometri, mikrotom, mikroskoup binokuler, mikroskoup fluorescen, kamera mikroskoup, lamina air flow, autoclave dan peralatan standar untuk budidaya jaringan.

\section{Metode penelitian}

\section{Ekstraksi kayu sengon}

Materi dididihkan dalam alkohol 13 menit untuk menonaktifkan enzim fenolase, kemudian dihaluskan dengan blender. Homogenat diekstraksi dengan metanol $70 \%$ sebanyak dua kali menggunakan rotary shaker. Larutan ekstrak disentrifugasi dengan kecepatan 5000 rpm selama 10 menit. Lapisan 
organik dipisahkan dan diuapkan sampai kering dengan gas nitrogen pada suhu $50^{\circ} \mathrm{C}$. Pengujian fenol total dilakukan dengan melarutkan residu dalam metanol $50 \%$ setelah disimpan dalam freezer.

\section{Penetapan kandungan fenol total}

Kandungan fenol total ditetapkan secara spektrofotometri dengan metode yang dikembangkan oleh Singleton dan Rossie (1965) dengan pereaksi FolinCiocalteu, menggunakan asam galat sebagai standar. Kadar fenol total dihitung dengan memasukkan nilai serapan sampel pada panjang gelombang $765 \mathrm{~nm}$ ke dalam persamaan garis regresi linear $\mathrm{Y}=\mathrm{ax}+\mathrm{b}$, yang diperoleh dari kurva kalibrasi. Hasil dinyatakan dalam satuan $\mathrm{mg}$ ekivalen asam galat per 100 gram (mg ek-AG/100 gram).

\section{Anatomi jaringan cabang sengon}

Preparat yang digunakan pada penelitian sifat anatomi adalah preparat dari sayatan penampang transversal sampel. Tahapan penelitian yang dilakukan pada penelitian ini sesuai dengan Nugroho et. al (2005). Potongan sampel sekitar $2 \mathrm{~cm}$ difiksasi dengan larutan gliseraldehid selama 24 jam, selanjutnya dicuci dengan etanol $30 \%$ dan direndam dalam larutan etanol 30\%. Penyayatan dilakukan pada bagian penampang transversal menggunakan alat mikrotom dengan ketebalan $\pm 15-20$ mikron. Sayatan yang terbaik (tipis dan tidak sobek) yang dihasilkan diletakkan pada kaca obyek. Kemudian dilakukan pewarnaan menggunakan cairan safranin $1 \%$ sebanyak 3-5 tetes. Setelah diberi warna kemudian dikeringkan dan ditetesi xylol sebanyak 2-3 tetes untuk menguapkan sisa alkohol dan gelembung udara yang ada, untuk mempercepat proses penguapan dapat dipanaskan di atas kompor pemanas. Irisan ditetesi dengan Canada balsam ditutup dengan kaca penutup. Preparat yang telah jadi dikeringkan dan diletakkan dalam kotak preparat. Preparat yang sudah jadi diletakkan di atas meja obyek mikroskop dan dilakukan pemotretan terhadap gambar sel yang lengkap menggunakan optilab.

\section{Kalugenesis sengon melalui}

\section{budidaya jaringan}

Induksi dan subkultur dilakukan pada media kalus MS (Murashige, 1974) dengan hormon pertumbuhan BAP (Benzyl Amino Purin) $2 \mathrm{mg} / \mathrm{l}$ dan NAA (Naphtalene Acetic Acid) 0,5 mg/1, sukrose $30 \mathrm{~g} / 1$ sebagai sumber karbohidrat dan gelerite $4 \mathrm{~g} / 1$ sebagai pemadat media. $\mathrm{pH}$ media diatur pada kemasaman 5,7 dengan $\mathrm{NAOH}$ dan $\mathrm{HCl}$.

\section{Ekstraksi gal karat tumor}

Prosedur ekstraksi dilakukan secara maserasi kinetik yang mengacu pada 
metode yang digunakan Pachanawan et al., 2008 dengan beberapa modifikasi. Perendaman serbuk $U$. tepperianum dilakukan dalam pelarut etanol $95 \%$ dengan perbandingan 1:10 (w/v). Ekstrak diencerkan dengan dimetil sulfoksida. Prosedur ekstraksi maserasi dengan Etanol 95\% adalah dengan merendam serbuk $U$. tepperianum dalam pelarut dengan perbandingan 1:10 (w/v), pada penelitian ini merendam 10 gram sampel pada 100 $\mathrm{mL}$ etanol $95 \%$ selama 72 jam pada suhu ruang untuk melarutkan komponen bioaktif, kemudian disaring dengan saringan ukuran $\pm 1,2 \mathrm{~mm}$. Penyaringan selanjutnya digunakan saringan yang lebih kecil $\pm 0,6 \mathrm{~mm}$, penyaringan terakhir dengan kertas saring Whatman no. 125. Filtrat diuapkan dengan rotary vacuum evaporator pada $70^{\circ} \mathrm{C}$ di water bath. Akhirnya ekstrak kental ditempatkan di piring porselin, terus diaduk dan dipanaskan pada $70^{\circ} \mathrm{C}$ di water bath. Ekstrak diencerkan dengan dimetil sulfoksida.

\section{Penghitungan sel kalus sengon yang hidup}

Penghitungan sel hidup kalus sengon dilakukan melalui mikroskop fluoresen Nikon ECLIPSE 50i dengan kamera DS-U2 dengan pengecatan sel menggunakan Fluoresence diacetat (FDA). Substrat esterase fluorogenik FDA dikonversi oleh esterase intraseluler menjadi analog fluoresen hijau. Senyawa ini dapat ditangkap karena sel-sel kalus bermuatan negatif dan dapat tersediakan sesuai daya tangkapnya. Pencucian sel setelah inkubasi di media cair filtrat karat tumor mengunakan phosphate buffer saline (PBS) (Baumann, 2014).

\section{E. Rancangan Percobaan}

Ekstraksi batang sengon maupun ekstraksi gal karat tumor dilakukan secara duplo, penetapan kandungan fenol total dilakukan dengan 3 ulangan untuk 3 famili toleran, 3 famili tidak toleran dan 1 famili tanpa inokulasi. Masing-masing famili menggunakan 3 sampel bagian pangkal, tengah dan ujung. Kurva standar untuk analisis fenol total dibuat dengan kadar 0 ; 0,$1 ; 0,5 ; 1 ; 2,5 ; 5 \mu \mathrm{g} / \mathrm{mL}$ dengan 2 absorbansi. Pengamatan mikroskopis anatomi jaringan cabang berdasarkan hasil pengamatan obyek terbaik dari 10 penampang/bidang pandang yang berbeda. Materi kalugenesis menggunakan 50 sampel eksplan, subkultur kalus dilakukan setiap 30 hari sebanyak 3 kali subkultur. Perlakuan sel kalus pada media cair filtrat gal karat tumor dilakukan pada konsentrasi $100 \%, 75 \%, 50 \%, 25 \%$ dan $0 \%$ (kontrol). Pengamatan mikroskopis sel kalus hidup berdasarkan hasil pengamatan obyek terbaik dari 10 penampang/bidang pandang yang berbeda. Rata-rata dari 
setiap beberapa parameter yang diukur digunakan untuk analisa keragaman (Analysis of variance). Apabila terdapat keragaman antar perlakuan yang diuji, maka dilanjutkan dengan Uji Jarak Berganda Duncan (Duncan's Multiple Range Test-DMRT) untuk melihat perbedaan antar perlakuan yang diuji. Analisa sidik ragam dan uji jarak berganda Duncan dilakukan menggunakan program computer SPSS versi 16.

\section{HASIL DAN PEMBAHASAN}

\section{Tinggi tanaman pada toleransi} sengon terhadap karat tumor

Penelitian ini merupakan rangkaian analisis kuantitatif dan diskriptif untuk mengamati senyawa fenol total pada toleransi sengon terhadap penyakit karat tumor. Materi sengon toleran dan tidak toleran yang digunakan dalam penelitian ini mempunyai perbedaan pertumbuhan dan perkembangan selama 18 bulan inkubasi setelah inokulasi buatan spora karat tumor. Penelitian keterkaitan antara pertumbuhan, kandungan metabolik sekunder fenol dan pertahanan terhadap penyakit belum sepenuhnya dipelajari terutama pada tanaman pohon.

Produksi metabolik sekunder tidak berkaitan atau tidak secara langsung berkaitan dengan pertumbuhan dan perkembangan tanaman karena secara umum tidak terlibat pada proses fotosintesis, respirasi, transportasi larutan, translokasi, asimilasi nutrient dan diferensiasi (Hartmann, 1991). Pendapat lain mengemukakan bahwa sebagian besar dari 100.000 metabolit sekunder yang telah diketahui, terlibat dalam sistem biokimia tanaman untuk pertahanan dari tekanan lingkungan abiotik maupun biotik termasuk serangan hama penyakit, yang terbentuk dalam kurun waktu yang sangat panjang selama tanaman beregenerasi (Simms, 1992; Karban \& Baldwin, 1999; Harvell \& Tolrian, 1999; Stotz et al., 1999; Siemens et al., 2002).

Perbedaan pertumbuhan berdasarkan tinggi tanaman antara 3 famili sengon tidak toleran dan 3 famili sengon toleran yang digunakan sebagai materi pada penelitian ini ditunjukkan pada Gambar 1.

Untuk mengetahui variasi tinggi tanaman setelah 18 bulan inkubasi dilakukan analisis varian yang menunjukkan adanya pengaruh yang sangat nyata untuk tinggi tanaman antara sengon toleran dan tidak toleran karat tumor, hal ini mengindikasikan adanya variasi genetik dari karakteristik tinggi tanaman terhadap toleransi (Tabel 1). Pada Tabel 2 berdasarkan hasil uji jarak berganda Duncan menunjukkan adanya pengelompokkan sengon toleran, tidak toleran dan kontrol. 
Tabel 1. Analisis varian tinggi tanaman sengon toleran dan tidak toleran karat tumor setelah 18 bulan inkubasi di persemaian.

\begin{tabular}{llllll}
\hline \multicolumn{1}{c}{ Sumber variasi } & derajat bebas & Jumlah Kuadrat & $\begin{array}{c}\text { Kuadrat } \\
\text { tengah }\end{array}$ & F & Sig. \\
\hline Famili & 3 & 69268,551 & 23089,517 & $232,254^{* *}$ & 0,000 \\
Galat & 236 & 23461,912 & 99,415 & \\
Total & 239 & 92730,463 & & & \\
\hline
\end{tabular}

Keterangan **: pengaruh nyata pada taraf uji $1 \%$

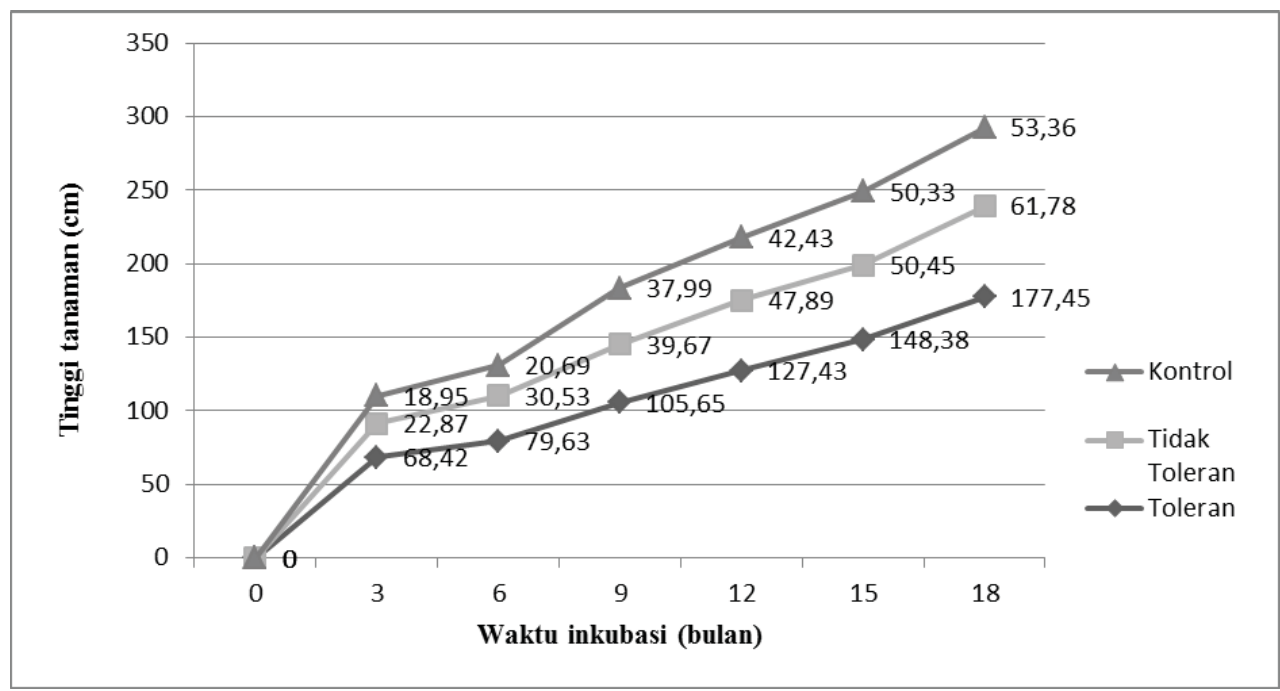

Gambar 1. Rata-rata tinggi tanaman sengon toleran, sengon tidak toleran dan sengon kontrol (tanpa inokulasi) selama 18 bulan inkubasi

Tabel 2. Uji jarak berganda Duncan untuk variabel tinggi tanaman sengon toleran dan tidak toleran karat tumor setelah setelah inkubasi 18 bulan di persemaian

\begin{tabular}{|c|c|c|c|c|c|}
\hline \multirow[t]{2}{*}{ No. } & \multirow{2}{*}{ Varian } & \multirow{2}{*}{$\mathrm{N}$} & \multicolumn{3}{|c|}{ Subset untuk $\alpha 0,05$} \\
\hline & & & 1 & 2 & 3 \\
\hline 1. & $\begin{array}{l}\text { Sengon toleran } \\
\text { (TFA2, TFA6, TFA 35) }\end{array}$ & 60 & 177,442 & & \\
\hline 2. & $\begin{array}{l}\text { Sengon tidak toleran } \\
\text { (TTFA 28) }\end{array}$ & 60 & & 53,3600 & \\
\hline 3. & $\begin{array}{l}\text { Kontrol } \\
\text { (tanpa inokulasi) }\end{array}$ & 60 & & & 61,7800 \\
\hline
\end{tabular}

\section{Analisis kuantitatif senyawa fenol}

\section{total}

Hasil analisis senyawa fenol total sengon toleran, tidak toleran karat tumor dan kontrol setelah 18 bulan inkubasi ditunjukkan pada Gambar 2. Kandungan fenol yang tinggi pada kontrol (tanpa inokulasi) menunjukkan bahwa tanaman sengon secara umum mempunyai kemampuan menghasilkan fenol sebagai bagian program normal untuk pertumbuhan dan perkembangannya disamping sebagai respon adanya tekanan lingkungan. Kandungan senyawa antibiotik pada tanaman sehat yang terbentuk sebelum serangan merupakan pertahanan kimia terhadap berbagai potensi serangan patogen (Lattanzio et al., 2006). 
Rendahnya kandungan fenol pada sengon terinokulasi (toleran maupun tidak toleran) sampai dengan 18 bulan inkubasi dapat disebabkan rendahnya senyawa endogen fenol akibat interaksi sifat spesifik obligat parasit karat tumor dengan tanaman sengon. Perubahan ekspresi senyawa endogen fenol tanaman berkaitan dengan interaksi tanaman inang dengan patogen (Lattanzio et al., 2006).

Ketergantungan mutlak karat tumor terhadap sengon sebagai sumber karbon dan energi setelah infeksi dan tingginya tekanan biotik inokulan patogen $U$. tepperianum memungkinkan terjadinya realokasi sumber energi tanaman inang lebih untuk pertumbuhan dan perkembangan yang terhambat akibat senyawa-senyawa toksik dalam patogenesis atau efek endogen fenol. Sistem pertahanan memerlukan realokasi energi dan perubahan aktivitas fisiologis tanaman inang (Simms \& Rausher 1987; Herms \& Mattson 1992; Simms \& Triplett 1994; Bergelson \& Purrington 1996; Mauricio et al., 1993), serta peningkatan reaksi aktivasi seperangkat gen pengkode protein penginduksi biokimia penting yaitu protein terkait patogenesis (Pathogenesis Related Protein) (Ebrahim et al., 2011). Salah satu pengaruh pembentukan senyawa fenolik tanaman adalah terhambatnya aktivitas hormon pertumbuhan auksin yaitu indoleacetic acid (IAA) serta terhambatnya transport IAA lintas membrane plasma (Mahesius, 2001).

Pada Gambar 2 juga menunjukkan bahwa 3 famili sengon toleran karat tumor mempunyai kandungan fenol total yang lebih rendah dibandingkan sengon tidak toleran. Fenol dapat terakumulasi di sel-sel tanaman akibat rendahnya efisiensi sistem ekskresi (Lattanzio et al., 2006). Sengon toleran dimungkinkan mempunyai sistem ekskresi yang lebih baik karena mempunyai sistem metabolisme ketahanan yang lebih baik pula. Toleransi sengon terhadap infeksi karat tumor adalah kemampuan tanaman inang untuk mengurangi pengaruh infeksi terhadap kekokohannya. Dengan demikian meskipun toleransi ditentukan oleh meningkatnya pembentukan senyawa fenol sebagai sistem pertahanan tanaman, efisiensi ekskresi menentukan pengaruh penurunan metabolisme akibat akumulasi fenol.

Penggunaan materi cabang sengon pada penelitian ini menunjukkan adanya akumulasi senyawa fenol total, dengan demikian organ cabang dapat dipergunakan untuk mengindikasikan senyawa fenol total akibat serangan karat tumor. Penggunaan cabang pada Calliandra brevipes Benth (Fabaceae: Mimosoidae) yang terserang 
penyakit penginduksi gal Tanaostigmodes ringueleti dan $T$. mecanga sebagai materi penelitian yang dilakukan Detoni et al., 2011 menunjukkan respon indikasi kandungan fenol yang nyata akibat pengaruh variasi tekanan lingkungan hidro (hydric stress).

Fenol pada gal karat tumor merupakan salah satu ko-faktor penentu pertahanan kimia sengon dan patogenitas U. tepperianum. Hal ini ditunjukkan oleh tingginya senyawa fenol total pada gal (Gambar 2). Gal (neoplasmik) mengandung berbagai senyawa toksin yang berperan sebagai co-factor penentu patogenisitas dari hasil perkembangan penyakit (Buiatti \& Ingram, 1991; Crino, 1997; Svabova \& Lebeda, 2005). Analisis senyawa pada sistem gal secara umum berhubungan dengan interaksi pertahanan kimia tanaman dan patogen di alam (Detoni et al., 2011). Interpretasi senyawa di sistem gal ini penting sebagai dasar penggunaan filtrat gal untuk agen selektif patogen obligat biotrop seperti $U$. tepperianum pada teknik induksi toleransi in vitro.

\section{Pengamatan uji sel kalus sengon pada media filtrat karat tumor in vitro}

Hasil analisis senyawa fenol total gal karat tumor pada penelitian ini menjadi dasar upaya pemanfaatan filtrat gal sebagai agen selektif untuk teknik induksi toleransi sengon in vitro. Uji ini penting dilakukan karena $U$. tepperianum bersifat obligat biotrop, tidak dapat dibudidaya pada media buatan sehingga filtrat patogen tersebut tidak dapat digunakan sebagai agen selektif. Beberapa penelitian menunjukkan filtrat kultur fungi, fitotoksin atau patogen merupakan agen seleksi in vitro yang efektif untuk ketahanan /toleransi suatu penyakit (Purohit et al., 1998; Mohamed et al., 2000). Seleksi in vitro dimaksudkan untuk mendukung teknik seleksi konvensional tanaman pohon yang nisbi sangat lama beregenerasi.

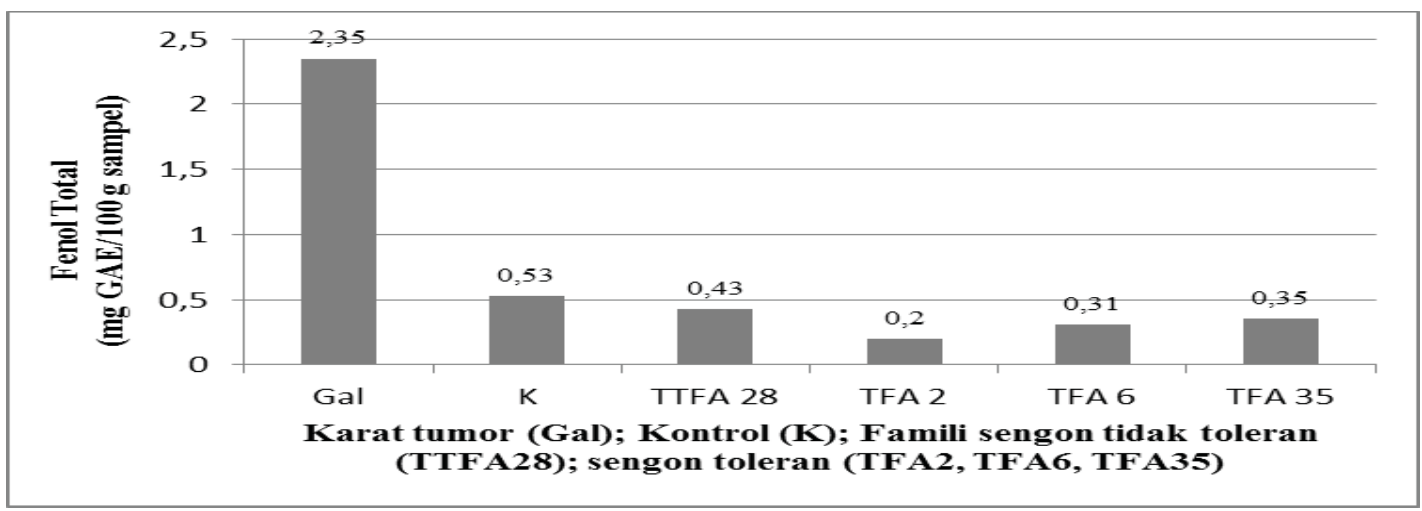

Gambar 2. Kandungan senyawa fenol total sengon toleran, tidak toleran karat tumor dan kontrol setelah 18 bulan inkubasi. 


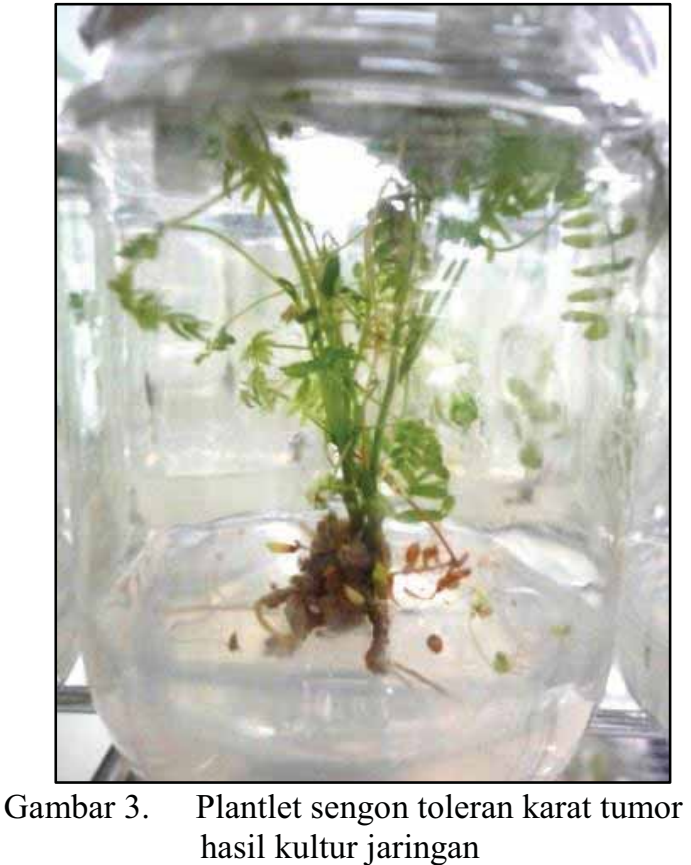

Pengujian toleransi sengon in vitro pada penelitian ini didasarkan pada sel kalus hidup pada konsentrasi tertinggi media cair filtrat karat tumor. Penggunaan senyawa toksin sebagai agen seleksi in vitro berpotensi efektif pada penyakit yang disebabkan oleh toksin dari patogen yang sama (Kuehnle \& Earle 1992). Plantlet sengon toleran karat tumor hasil budidaya jaringan (Gambar 3.) digunakan sebagai materi kalugenesis pada penelitian ini (Gambar 4A).

Uji toleransi kalus sengon pada media filtrat karat tumor ditunjukkan pada Gambar 4B. Hasil pengamatan mikroskopis sel-sel kalus hidup menggunakan fluorescein diacetat (FDA) dibandingkan pengamatan sel-sel kalus tanpa FDA ditunjukkan pada Gambar 5. Pada penelitian ini sel-sel kalus hidup teramati di 10 bidang pandang mikroskop hasil uji 24 jam inkubasi sel kalus dalam filtrat karat tumor dengan konsentrasi tertinggi $25 \% \quad(\mathrm{v} / \mathrm{v})$. Sel kalus sengon hidup yang ditandai adanya pendaran fluoresen hijau merupakan sengon toleran karat tumor pada tingkat sel melalui uji filtrat karat tumor sebagai agen seleksi in vitro. Penelitian lebih lanjut diperlukan untuk uji regenerasi in vitro kalus sengon proembriogenik sampai tahap aklimatisasi.
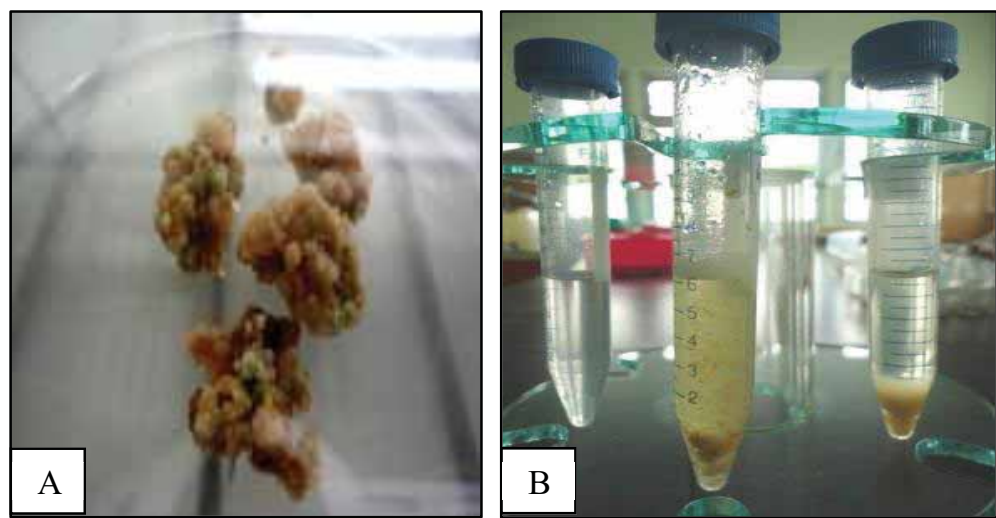

Gambar 4. Kalus sengon toleran karat tumor hasil kultur jaringan (A) dan uji seleksi kalus sengon pada media filtrat karat tumor (B). 

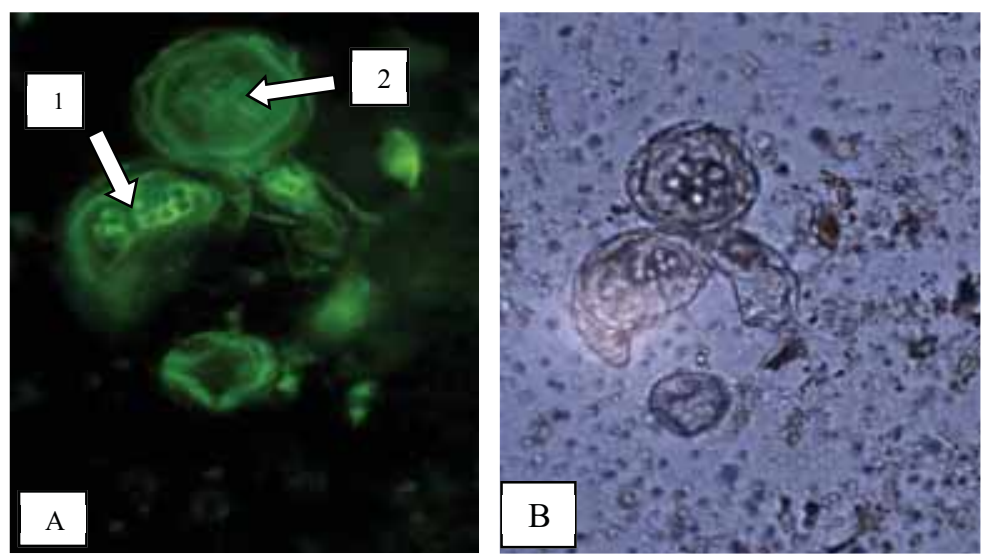

Gambar 5. Sel kalus hidup mikroskopis (400x) menggunakan fluorescein diacetat (FDA), sel kalus toleran berpendar hijau (A1) dan tidak toleran (A2), dibandingkan sel kalus tanpa FDA (400x) (B).

\section{Analisis anatomi kayu sengon terserang karat tumor}

Hasil pengamatan analisis anatomi kayu sengon terserang karat tumor menunjukkan adanya bulatan-bulatan berwarna hitam atau gelap pada irisan melintang batang yang tidak terjadi pada kayu sengon tidak terserang karat tumor (Gambar 6). Pada penelitian yang telah dilakukan oleh Rukhama \& Nugroho, (2014) bagian tersebut merupakan parenkim yang disebut dengan dark substrate content. Parenkim akan terbentuk dalam jumlah yang besar pada jaringan tumor tanaman yang digunakan untuk pembentukan sambungan floem (phloem anastomoses) (Aloni et al., 1994).

Anatomi kayu Pinus densiflora mengalami penurunan jumlah trakeid, jumlah saluran resin dan jari-jari cabang pada kayu yang terinfeksi karat tumor (Yamamoto et al., 1998). Menurut Jawell (1988), batang pinus terinfeksi mempunyai jari-jari apotrakeal (xylem ray) dan jari-jari floem lebih rapat, jumlah sel parenkim floem meningkat, hiperplasia di korteks serta batas kambium menjadi tidak terlihat.
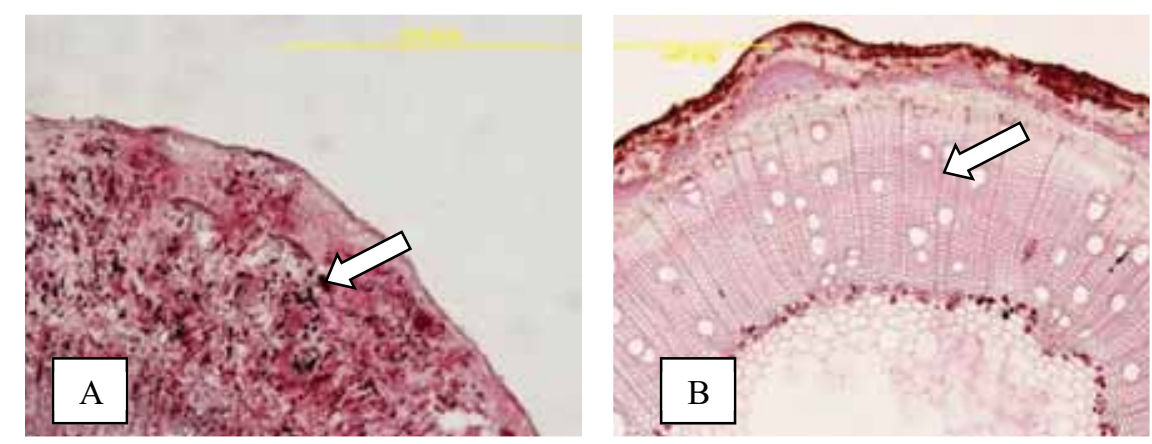

Gambar 6. Anatomi kayu sengon terserang karat tumor, terdapat dark substrate content (A) dan anatomi kayu sengon tidak terserang karat tumor, parenkim tanpa dark substrate content (B). 
Tingginya hasil analisis senyawa fenol pada gal karat tumor dan pada sengon tidak toleran karat tumor ditengarai berkaitan dengan dark substrate content pada parenkim. Parenkim kayu (wood parenchym) terbentuk oleh sel-sel pembentuk unsur-unsur trakea dengan dinding sel mengalami penebalan sekunder. Parenkim kayu berfungsi sebagai tempat penyimpan cadangan makanan seperti zat tepung atau lemak, terdapat pula senyawa fenolik seperti zat tannin, flavonoid, kristal-kristal atau zat lainnya (Sutrian, 2011). Dengan demikian bila senyawa fenol tidak terekskresikan dengan baik akan tersimpan dalam parenkim, menunjukkan substrat dengan warna gelap.

\section{KESIMPULAN}

Kandungan senyawa fenol berkaitan dengan toleransi sengon terhadap penyakit karat tumor. Senyawa fenol dapat dipergunakan sebagai penanda biokimia toleransi sengon terhadap penyakit karat tumor melalui tinggi tanaman, anatomi kayu dan sebagai agen kimia pada uji toleransi sel kalus hasil bididaya jaringan. Pertumbuhan dan perkembangan tanaman sengon toleran karat tumor 332\% lebih baik dengan kandungan senyawa fenol total lebih rendah ditengarai mempunyai sistem ekskresi yang lebih baik dan mempunyai toleransi sel kalus lebih tinggi pada agen biokimia filtrat karat tumor dibandingkan tanaman sengon tidak toleran karat tumor.

\section{UCAPAN TERIMA KASIH}

Tulisan ini merupakan bagian dari disertasi S3 penulis pada Pasca Sarjana Universitas Gadjah Mada. Ucapan terima kasih penulis sampaikan kepada Balai Besar Penelitian Bioteknologi dan Pemuliaan Tanaman Hutan, Badan Penelitian dan Pengembangan Kehutanan dan Universitas Gadjah Mada. Terima kasih juga penulis ucapkan kepada rekanrekan peneliti dan para teknisi Laboratorium Budidaya Jaringan, Balai Besar Penelitian Bioteknologi dan Pemuliaan Tanaman Hutan.

\section{DAFTAR PUSTAKA}

Aloni, R., Prade, K. S. 1., \& Ullrich, C. I. (1994). The three-dimensional structure of vascular tissues in agrobacterium tumefaciens-induced crown galls and in the host stems of Ricinus communis $l$. Darmstadt, Jerman: Institut Fur Botanik.

Anggraeni, I. (2008). Penanggulangan Serangan Karat Puru pada Tanaman Sengon. Makalah Workshop, 19 Nop 2008. Balai Besar Penelitian Bioteknologi dan Pemuliaan Tanaman Hutan. Pusat Litbang Tanaman Hutan. Bogor, Indonesia.

Baumann, N. (2014). Live and Dead Staining with Fluorescein Diacetat (FDA) and Propidium Iodide (PI): Application note, 3, ibidi GmbH, version 1.0. Cells in Focus.

Bergelson, J., \& Purrington, C. B. (1996). Surveying Patterns in the Cost of Resistance in Plants. Am. Nat, 148, 536558.

Biro Pusat Statistik. (2006). Sensus Tanaman Pertanian 2003. Jakarta, Indonesia: Biro Pusat Statistik. 
Buiatti, M., \& Ingram, D. S. (1991). Phytotoxins as Tools in Breeding and Selection of Disease Resistant Plants. Experientia, 47, 811-819.

Crino, P. (1997). Culture Filtrate as Selective Agent of Resistance to Phytopathogenic Fungi. In R. K. Upadhyay \& K. G. Mukerji (Eds.), Toxins in Plant Disease Development and Evolving Biotechnology (pp 183-208). Enfield, New Hampshire, USA: Science Publishers Inc.

Detoni, L. M., Vasconcelos, E. G., Rust, N. M., Isaias, R. M. S., \& Soares, G. L. G. (2011). Seasonal Variation of Phenolic Content in Galled and Non-Galled Tissues of Calliandra brevipes Benth (Fabaceae: Mimosoidae). Acta Botanica Brasilica, 25(3), 601-604.

Ebrahim, S., Usha, K., \& Bhupinder, S. (2011). Pathogenesis Related (PR) Proteins in Plant Defense Mechanism. In A. MendezVilas (Ed.), Science Against Microbial Pathogens: Communicating Current Research and Technological Advances. New Delhi, India: Indian Agricultural Research Institute.

Finkeldey, R. (2005). Die Genetische Variation in Eichenpopulationen. In P. Bonfils, D. Horisberger, \& M. Ulber (Hrsg.), Förderung der Eiche. Strategie zur Erhaltung eines Natur-und Kulturerbes der Schweiz. Schriftenreihe Umwelt Nr. 383, (S. 31-32). Bern, Schweiz: ProQuercus und Bundesamt für Umwelt, Wald und Landschaft.

Hartmann, T. (1991). Alkaloids. In G. A. Rosenthal \& M. R. Berenbaum, (Eds.), Herbivores: Their Interaction with Secondary Plant Metabolites: Vol. I. The chemical participants, (2nd ed.) (pp. 33-85). San Diego: Academic press.

Harvell, C. D., \& Tollrian, R. (Eds.). (1999). Why Inducible Defenses? In The Ecology and Evolution of Inducible Defenses (pp. 39). Princeton, New Jersey: Princeton University Press.

Jewell, F. F. (1987). Phytopatology: Histopathology of Fusiform RustInoculated Progeny from (Shortleaf $x$ Slash) $x$ Shortleaf Pine Crosses. School of Forestry, Louisiana Tech University.

Karban, R., \& Baldwin, T. T. (1997). Induced Responses to Herbivory. Chicago: University of Chicago Press.

Kuehnle, A. R., \& Earle, E. D. (1992). Evaluation of In vitro Selection Regimes For A
Mitochondrial Trait (Methomyl

Resistance) in cms-T Maize. Plant Cell, Tissue and Organ Culture, 28, 129-37.

Lattanzio, V., Veronica, M. T., \& Cardinali, A. (2006). In F. Imperato (Ed.), Phytochemistry: Advances in Research, 23-67. ISBN: 81-308-0034-9

Mahesius, U. (2001). Flavonoids induced in cells undergoing nodule organogenesis in white clover are regulators of auxin breakdown by peroxidase. Journal of Experimental and Botany, 52, 419.

Maloy, O. C. (2005). Plant Disease Management. Department of Plant Pathology, Washington State University, Pullman, WA.

Marquis, R. J. (1984). Leaf Herbivores Decrease Fitness of a Tropical Plant. Science, 226, 537-539.

Maurico, R., Bowers, M. D., \& Bazzaz, F. A. (1993). Pattern of Leaf Damage affects Fitness of The Annual Plant Raphanus sativus (Brassicaceae). Ecology, 74, 20662071.

Mohamed, M. A. H, Harris, P. J. C., \& Henderson, J. (2000). In vitro Selection and Characterization of a Drought Tolerant Clone of Tagetes Minuta. Plant Sci., 159, 213-222.

Murashige, T. (1974). Plant Propagation Through Tissue Cultures. Annual Review Plant Physiology, 25, 135-166.

Nugroho, H., Purnomo \& Isirep, S. (2005). Struktur dan Perkembangan Tumbuhan. Jakarta: Penebar Swadaya.

Pachanawan, A., Phumkhachorn, P., \& Rattanachaikunsopon, P. (2008). Potential of Psidium guajava supplemented fish diets in controlling aeromonas hydrophila infection in tilapia (Oreochromis niloticus). J. Biosci. Bioeng., 106, 419424.

Paige, K. N., \& Whitham, T. G. (1987). Compention in Respon to Mammalian Herbivory: The Advantage of Being Eaten. American Naturalist, 129, 407-416.

Purohit, M., Srivastava, S., \& Srivastava, P. S. (1998). In P. S. Srivastava (Ed.), Stress Tolerant Plants Through Tissue Culture, Plant Tissue Culture and Molecular Biology: Application and Prospects (pp. 554-578). New Delhi: Narosa Publishing House. 
Rosenthal, J. P. \& Welter, S. C. (1995). Tolerance to Herbivory by a Stemboring Caterpillar in Architecturally Distinct Maizes and Wild Relative. Oecologia, 102, 146-155.

Rukhama, S., \& Nugroho, W. D. (2014). Anatomi tumor kayu pada sengon trubusan yang terserang jamur U. tepperianum (Skripsi). Fakultas Kehutanan, Universitas Gadjah Mada, Yogyakarta.

Scheffer, R. J. (2007). On Toxins and Aggressins. Plant Pathology, 31(3), 193-194. doi: 10.1111/j.1365-3059.1982.tb01267.x

Siemens, D. H., Garner, S. H., Mitchell-Olds, T., \& Callaway, R. M. (2002). Cost of Defense in The Context of Plant Competition: Brassica rapa May Grow and Defend. Ecology, 83(2), 505-517.

Simms, E. L. (1992). Costs of Plant Resistance to Herbivory. In Ecology, Evolution and Genetics, R. S. Fritz, \& E. L. Simms (Eds.). Plant Resistance to Herbivores and Pathogens (pp. 392-425). Chicago: University of Chicago Press.

Simms, E. L., \& Triplett, J. (1994). Cost and Benefits of Plant Responses to Dosease: Resistance and Tolerance. Evolution, 48, 1973-1985.

Singleton, V. L., \& Rossi (Jr.), J. A. (1965). Colorunetry of Total Phenolics with Phosphomolybdic-Phosphotungstic Acid Reagents. Department of Viticulture and Enology, University of Calitornia, Davis, CA. American Journal Enolology Viticult, $16,144-58$

Stotz, H. U., Kroymann, J., \& Mitchell-Olds, T. (1999). Plant insect Interactions. Current Opinion in Plant Biology, 2, 268-272.

Strauss, S. Y., \& Agrawal, A. A. (1999). The Ecology and Evolution of Plant Tolerance to Herbivory. Trends in Ecology and Evolution, 14(5), 179-185. doi: 10.1016/S0169-5347(98)01576-6

Sutrian, Y. (2011). Pengantar Anatomi Tumbuhtumbuhan Tentang Sel dan Jaringan. Rineka Cipta. ISBN 9789795180357.

Švábová, L., \& Lebeda, A. (2005). In vitro Selection for Improved Plant Resistance to Toxin-Producing Pathogens. Journal of Phytopathology, 153, 52-64.

Voegele, R. T., \& Mendgen, K. (2010). Nutrient Uptake in Rust Fungi: How Sweet is Parasitic Life. BGRI 2010 Technical Workshop, 30-31-May 2010, St. Petersburg, Russia.
Yamamoto, F., Sakata, T. \& Terazawa, K. (1995). Growth, Morphology, Stem Anatomy, and Ethylene Production in Flooded Alnus japonica Seedlings. IAWA J, 16, 47-59. 